\title{
Centaurea pterocaula özütlerinin antioksidan ve antimutajenik özellikleri ile enzim inhibitör potansiyellerinin incelenmesi
}

\author{
Ahmet UYSAL, Gökhan ZENGİN, Yusuf DURAK, Abdurrahman AKTÜMSEK
}

\section{ÖZ}

$\mathrm{Bu}$ çalışmanın amacı, Centaurea pterocaula bitkisinden elde edilen üç özütün (etil asetat, metanol ve su) antioksidan kapasiteleri, mutajenik/antimutajenik özellikleri ve enzim inhibitör etkilerini değerlendirmektir. Özütlerin antioksidan özellikler radikal giderme (süpürme) (DPPH testi), indirgeme gücü (FRAP ve CUPRAC testleri), fosfomolibdat ve metal şelatlama testleri gibi in vitro antioksidan yöntemler kullanılarak araştırıldı. Özütlerin enzim inhibitör etkiler kolinesteraz, tirozinaz, amilaz ve glukozidaza karşı test edildi. Ames testi özütlerin mutajenik/antimutajenik özelliklerini göstermek için kullanıldı. Metanol özütünün en güçlü radikal giderme (31.06 mgTE/g özüt) ve indirgeme gücüne (CUPRAC testinde $66.95 \mathrm{mgTE} / \mathrm{g}$ özüt ve FRAP testinde $51.03 \mathrm{mgTE} / \mathrm{g}$ özüt) sahip olduğu tespit edildi. Ayrıca, etil asetat özütü glikozidaz enzimi hariç test edilen tüm enzimlere karşı en güçlü etkiyi sergiledi. Özütlerin toplam fenolik ve flavonoid içerik sırasıly 15.77-25.22 mg GAE/g özüt ve 0.67-31.44 mg $\mathrm{RE} / \mathrm{g}$ özüt aralıklarında değiştiği bulundu. Test edilen özütlerin hiçbirinde mutajenik etki görülmezken, bazı örneklerin önemli oranda antimutajeniteye sahip olduğu tespit edildi. Metabolik aktivasyon (S9) varlığında etil asetat ve metanol özütlerinin 2-aminofloren'e karşı $5000 \mu \mathrm{g} /$ plak dozlarda çok güçlü (sırası ile \% 92 ve \% 92) antimutajenik etkiye sahip oldukları bulundu. Bu çalışmanın sonuçlarına göre, C. pterocaula yeni nutrasötik veya farmasötiklerin geliştirilmesinde potansiyel bir kaynak olarak düşünülebilir.

Anahtar kelimeler: Centaurea pterocaula, antioksidan, enzim inhibisyonu, antimutajenite, doğal ajanlar.
Ahmet Uysal

Selçuk Üniversitesi, Sağllk Hizmetleri Meslek Yüksekokulu Tibbi Hizmetler ve Teknikler Bölümü, Tibbi Laboratuvar Programi, Konya, Türkiye

Gokhan Zengin, Yusuf Durak, Abdurrahman Aktumsek Selçuk Üniversitesi, Fen Fakültesi, Biyoloji Bölümü, Konya, Türkiye

Sorumlu Yazar:

Ahmet Uysal

Tel: +903322231068

e-mail:ahuysal@selcuk.edu.tr

Gönderilme/Submitted: 28.03 .2016

Kabul/Accepted: 24.04.2016
Düzeltme /Revised: 21.04.2016

\section{GíRiş}

Günümüzde bilimsel araştırmaların temelinde sadece hastaları bireysel anlamda iyileştirmek değil, aynı zamanda toplumu etkileyen kitlesel sağlık sorunlarına çok yönlü çözümler üretmek ve bunlarla mücadelede rol oynayacak yeni kaynakların tespiti yatmaktadır. Bu amaçla birçok hastalık için sentetik çözümler sunulmasına karşllı toplumdaki sentetik ürünlerin tümü zararlı gibi kaygılar bu çözümleri şüpheli hale getirmektedir. Bu bağlamda bitkilerin tıbbi özelliklerine yönelik çalışmalar oldukça hız kazanmıştır.

Bitkilerin tıbbi özelliklerinin ortaya konulduğu çalışmalar değerlendirildiğinde, bitkiler tarafından üretilen "sekonder metabolit" olarak nitelendirilen bileşiklerin bu tıbbi özelliklerden sorumlu ana etken grup olduğu rapor edilmiştir. Son ylllarda özellikle beslenmede meyve ve sebze tüketimi ile kanser, kardiovasküler hastalıkları gibi kronik hastalıklara yakalanma riski arasında ters bir ilişki bulunduğu belirtilmiştir. Bu durumun özellikle sekonder metabolitlerden kaynaklandığı ve bu bileşikler içerisinde fenolik bileşiklerin 
diğer bileşenlere kıyasla daha etkin rol aldıkları rapor edilmiştir (1-3). Fenolikler yapılarında aromatik halkaya bağlı bir veya daha fazla hidroksil grubu içerirler ve flavonoidler, fenolik asitler, stilbenler ile lignanlar olarak dört temel sinıfa ayrıllrlar (4). Sağlıklı bir yaşam için flavonoidlerin diyetle alınması gerektiği ve bu durumun kalp damar sistemi üzerine olumlu etkiler gösterdiği belirtilmektedir. Örneğin, damar sistemi ile ilgili bozuklukların tedavisinde rutin ve hesperidinin etkin rol oynadığ gözlenmiştir. Fenolik bileşiklerin bu etkileri antioksidan özelliklerinden kaynaklandığı ileri sürülmüştür (5-7).

İnsan çevresi sürekli olarak mutajenik ve karsinojenik ajanlarla karşılaşmakta ve bu etkenlerin ortamdan uzaklaştırılması oldukça uğraştırıcı ve zor bir tablo ortaya koymaktadır. Son zamanlarda, bitkiler ve bitkisel bazı metabolitlerin antimutajenik potansiyele sahip bileşiklerin ana kaynakları olduğu kabul edilen bir gerçektir. Hatta bazı sekonder bitkisel metabolitler, genotoksik ajanlara karşı koruyucu etki göstermektedir. Bu antimutajenler ve antikarsinojenler, karsinojenik işlem basamaklarının birini ya da birkaçını inhibe ederek kanser oluşumunu önleyebilir (8). Bu bağlamda pek çok bitki türü antimutajenik potansiyelleri yönünden araştırılmıştır $(9,10)$.

Türkiye florası aromatik bitkilerin kaynağı olarak da büyük önem taşır ve ülkemizde yaklaşık 3000 civarında aromatik bitki olduğu varsayılmaktadır. Ülkemizde tıbbi amaçlı kullanılan bitki sayısı tam olarak bilinmemekle birlikte, 500 civarında olduğu tahmin edilmekte ve yaklaşık 200 tıbbi bitkinin ihraç potansiyelinin olduğu belirtilmektedir. Tüm bu belirtilen noktalar dikkate alındığında Anadolu'da geleneksel halk hekimliğine birçok hastalığın tedavisinde şifa kaynağı olarak başvurulmaktadır. Ancak, geleneksel halk hekimliği hakkında bilimsel veriler oldukça sınırlıdır (11).

Asteraceae familyasının Centaurea cinsi dayanıklı, otsu, tek, iki veya çok yıllık yaklaşık 500 tür içerir ve Asya, Avrupa ve Kuzey Amerikanın birçok kısmında dağılım gösterir (12). Ülkemizde bu cins 179 türle temsil edilir ve bu türlerden 111 tanesi endemik olup endemizm oranı \%61'dir (13). Bu endemizm oranı ile Türkiye florasında bünyesinde en çok endemik tür bulunduran 3. cins konumundadır ve bu durum bitkinin gen merkezinin Türkiye olduğunun bir göstergesidir. $\mathrm{Bu}$ cinse ait birçok tür geleneksel halk hekimliğinde kullanılmaktadır. Örneğin, C. drabifolia, C.pulchella ve C. solsitalis abse, hemoroid ve soğuk algınlı̆̆ tedavisinde, $C$. aspera kan şekerini düşürücü, $C$. behen sarllık tedavisinde ve afrodizyak olarak, C. calcitrapa diüretik, temizleyici, tonik etkili ve sarılık ile soğuk algınlığ tedavisinde, C. cyanus ise diüretik, kan durdurucu olarak kullanılmaktadır. Ayrıca, $C$. acaulis, C. centaurium, C. cyanus, C. monantha, C. nigra, C. salonitana ve C. scabiosa anti-kanser ve anti-tümor özelliklere sahiptir $(14,15)$. Centaurea cinsine ait bazı türlerin çeşitli kısımlarının fitokimyasal ve biyolojik aktiviteleri bilimsel çalışmalarla ortaya konulmuştur (16).

Centaurea cinsine ait bazı türlerin halk hekimliğinde yoğun olarak kullanılmasından dolayı, bu cinse ait olan diğer türlerin biyolojik özelliklerinin tespiti oldukça önem arz etmektedir. Ayrıca bu türlerin etken maddelerinin izole edilerek, farmakolojik olarak değişik amaçlarla kullanılan hazır ürünler halinde sunulabileceği belirtilmektedir (17). Bu bağlamda bu çalışmada $C$. pterocaula'dan elde edilen üç özütün antioksidan, antimuajenik özellikleri ve çeşitli farmakolojik enzimleri inhibe etme potansiyellerinin araştırılması amaçlanmıştır. C. pterocaula'nın antioksidan bazı antioksidan özellikleri rapor edilmiş (18) olmasına rağmen mevcut çalışma oldukça kapsamlı olup, mutajenik/ antimutajenik aktivite ve enzim inhibisyonları açısından ilk olma özelliği taşımaktadır.

\section{GEREÇ ve YÖNTEMLER}

\section{Bitki materyali ve özütlerin çıkarılması}

Centaurea pterocaula bitkisi, 2014 yılı Ağustos ayında Konya ili Cihanbeyli ilçesi Gölyazı ile Günyüzü köyleri arasından toplandı. Bitkinin botanik tanımlaması Selçuk Üniversitesi Fen Fakültesi Biyoloji Bölümü Öğretim Üyesi Dr. Evren Yıldıztugay tarafından yapıldı (Örnek No: EY 2976). Bitkinin toprak üstü kısımları toplanarak gölgede kurutulduktan sonra değirmende iyice toz haline getirildi. Bitkinin etil asetat ve metanol özütleri, $10 \mathrm{~g}$ ögütülmüş bitki materyali 200 ml çözücü ile oda sıcaklığında 24 saat karıştırılmasıyla elde edildi. Özütlerin çözücüleri rotary-evaporator kullanılarak uzaklaştırıldı. Su özütü için ise $10 \mathrm{~g}$ öğütülmüş bitki tohumları $300 \mathrm{ml}$ kaynar su ile $15 \mathrm{dk}$ karıştırıldı ve liyofilize edildi.

\section{Toplam Fenolik Madde Tayini}

Yöntemde, bitkisel özütlerden $(2 \mathrm{mg} / \mathrm{ml}) 250 \mu \mathrm{l}$ deney tüplerine alındı ve sonra her bir tüpe $1 \mathrm{ml}$ Folin-Ciocalteu reaktifi (1:9 oranında seyreltilmiş) ilave edildi. Ardından her bir tüpe $750 \mu \mathrm{l} \% 1$ 'lik $\mathrm{Na}_{2} \mathrm{CO}_{3}$ çözeltisinden eklendi. Karışımlar oda sıcaklığında karanlıkta 2 saat bekletildikten sonra 765 nm'de absorbansları ölçüldü (Shimadzu UV-1800). Aynı işlemler standart olarak kullanılan gallik asit için de tekrarland. Bitkilerin fenolik madde içeriği g özütte gallik asit eş değeri (mg GAE/g) olarak verildi (19).

\section{Toplam flavonoid madde tayini}

Yöntemde, bitkisel özütlerden $(1 \mathrm{mg} / \mathrm{ml}) \quad 1 \mathrm{ml} \mu \mathrm{l}$ deney tüplerine alındı ve sonra her bir tüpe $1 \mathrm{ml}$ metanolik $\mathrm{AlCl}_{3}$ 
çözeltisi ilave edildi. 10 dakika bekledikten sonra 415 nm'de karışımın köre karşı absorbansı belirlendi. Aynı işlemler standart flavonoid olan rutin için de yapılarak rutine ait kalibrasyon eğrisi çizildi. Sonuçta özütlerin toplam flavonoid madde içerikleri g özütte rutin eş değer (mg RE/g) olarak verildi (20).

\section{DPPH radikal giderme (süpürme) aktivitesinin belirlenmesi}

Bitkisel özütlerin DPPH radikali süpürme aktivitesi Sarikurkcu (21)'ye göre yapıldı. Metanolik DPPH çözeltisi $\% 0.004$ 'lük olacak şekilde hazırlandı. Bitkisel özütlerin 1 ml'si hazırlanan DPPH çözeltisinin 4 ml'si ile karıştırıldı. Tüpler ağızları kapatılıp kuvvetlice karıştırıldıktan sonra oda sıcaklığında karanlıkta 30 dakika bekletildi. Bu süre sonunda absorbanslar 517 nm'de okundu. Aynı işlemler troloks için de yapıldı ve bitkisel özütlerin DPPH radikalini giderme (süpürme) aktiviteleri g özütte troloks eş değer olarak verildi (mgTEs/g).

\section{FRAP testi}

FRAP testinin uygulanmasında öncelikle FRAP reaktifi hazırland. FRAP reaktifi, $0.3 \mathrm{M}$, pH'sı 3.6 olan asetat tamponu, $10 \mathrm{mM}$ TPTZ ve $20 \mathrm{mM} \mathrm{FeCl}_{3}$ 'ün 10:1:1 oranında karıştırılması ile hazırlandı. Bitkisel özütlerin $0.1 \mathrm{ml}$ 'si hazırlanan FRAP reaktifinin 2 ml'si ile karıştırıldı ve oda sıcaklığında 30 dakika inkübasyona bırakıldı. Karışımların absorbansları 593 nm’de okundu. Testin sonuçları g özütte troloks eşdeğer olarak değerlendirildi (mgTE/g) (22).

\section{CUPRAC testi}

Yöntemde bitkisel özütlerden $0.5 \mathrm{ml}$ alındı ve her bir deney tüpüne $1 \mathrm{ml} \mathrm{CuCl} \cdot 2 \mathrm{H}_{2} \mathrm{O}(10 \mathrm{mM}), 1 \mathrm{ml}$ amonyum asetat ( 1 M; pH:7) ile $1 \mathrm{ml}$ neokuproin (7.5 mM) çözeltileri eklendi. Tüpler ağızları kapalı bir biçimde oda sıcaklığında karanlıkta 30 dakika bekletildi. Bu süre sonunda absorbansları 450 nm'de okundu. Testin sonuçları g özütte troloks eşdeğer (mgTE/g) olarak yorumlandı (23).

\section{Fosfomolibdat testi}

$\mathrm{Bu}$ Yöntemde $2 \mathrm{mg} / \mathrm{ml}$ konsantrasyonunda bitkisel özütlerden $0.3 \mathrm{ml}$ bir tüpe alındı ve bunun üzerine reaktif çözeltisinden $\left(0.6 \mathrm{M} \mathrm{H}_{2} \mathrm{SO}_{4}, 28 \mathrm{mM} \mathrm{Na}_{2} \mathrm{HPO}_{4} \cdot 12 \mathrm{H}_{2} \mathrm{O}\right.$ ve 4 $\mathrm{mM}$ amonyum molibdat) $3 \mathrm{ml}$ eklendi. Tüpler kuvvetlice karıştırılıp $95^{\circ} \mathrm{C}$ 'de 90 dakika inkübe edildi. İnkübasyon sonunda çözeltilerin absorbansı 695 nm’de okundu. Aynı işlemler standart antioksidan olarak kullanılan troloks için de yapıldı. Antioksidan aktivite g özütte troloks eşdeğeri (mmolTE/g) olarak hesapland 1 (24).

\section{Metal şelatlama aktivitesi}

Örneklerin $\mathrm{Fe}^{2+}$ iyonlarını şelatlama kapasiteleri Dinis ve ark. (25) yöntemine göre belirlendi. İçerisinde $2 \mathrm{ml}$ bitkisel özüt ( $1 \mathrm{mg} / \mathrm{ml}$ ) bulunan deney tüplerine $2 \mathrm{mM} 0.05 \mathrm{ml} \mathrm{FeCl}{ }_{2}$ çözeltisi ilave edildi. Tepkime $0.2 \mathrm{ml} 5 \mathrm{mM}$ ferrozin ilavesiyle başlatıldı. Tüpler karıştırıldıktan sonra oda sıcaklığında 10 dakika inkübasyona bırakıldı ve daha sonra 562 nm'de absorbans ölçümü yapıldı. Aynı işlemler şelatlayıcı ajan olan EDTA içinde yapıldı. Testin sonuçları g özütte EDTA eş değer olarak değerlendirildi (mg EDTA/g).

\section{Enzim İnhibisyonuna Yönelik Testler}

\section{Anti-kolinesteraz aktivitesi}

Kolinesteraz inhibitör aktivite Ellman's yöntemi kullanılarak 96 kuyucuklu mikroplakalarda ölçülmüştür (26). Mikroplakadaki kuyucuklara $2 \mathrm{mg} / \mathrm{ml}$ konsantrasyondaki $50 \mu \mathrm{l}$ bitki özütü, $125 \mu \mathrm{l}$ DTNB (5,5-Ditiyo-bis(2nitrobenzoik) asit), $25 \mu \mathrm{l}$ Tris- $\mathrm{HCl}$ tamponun ( $\mathrm{pH}$ 8.0)'da hazırlanmış AChE veya BChE enzim çözeltisi konuldu. Bu karışım oda sıcaklığında 15 dakika bekletildikten sonra $25 \mu \mathrm{l}$ asetiltiyokolin iyodür (ATCI) veya butiriltiyokolin iyodür (BTCI) eklendi. Benzer şekilde, $\mathrm{AChE}$ veya $\mathrm{BChE}$ enzim çözeltisi olmadan hazırlanmış tepkime reaktiflerine örnek çözeltisi eklenerek kör hazırlandı. Örnek ve körlerin absorbansları oda sıcaklığında 10 dakika inkübe edildikten sonra $405 \mathrm{~nm}$ de okundu. Körlerin absorbansları örneklerden çıkarılarak gerçek absorbanslar elde edilidi. Kolinesteraz inhibitör aktiviteleri g özütte galantamine eşdeğer olarak hesaplandı (mg GALAE/g).

\section{Anti-amilaz aktivitesi}

a-amilaz inhibitör aktivite Caraway-Somogyi iyot/potasyum iyodür (IKI) yöntemi kullanılarak gerçekleştirildi (8). Mikroplakadaki kuyucuklara $25 \mu \mathrm{l}$ örnek çözelti ve fosfat tamponunda (pH 6.9, $6 \mathrm{mM}$ sodyum klorür) hazırlanmış $50 \mu \mathrm{l}$ a- amilaz çözeltisi eklendi ve $37^{\circ} \mathrm{C}$ de 10 dakika inkübe edildi. Daha sonra inkübe edilmiş örneklere \% 0.05 'lik $50 \mu \mathrm{l}$ nişasta çözeltisi ilave edildi. Benzer şekilde, $\alpha$-amilaz enzim çözeltisi olmadan hazırlanmış reaksiyon reaktiflerine örnek çözeltisi eklenerek kör hazırlandı. Karışım $37^{\circ} \mathrm{C}$ de 10 dakika inkübe edildi. 1 M $25 \mu \mathrm{HCI}$ ilave edilerek reaksiyon durduruldu ve bunu takiben $100 \mu \mathrm{l}$ iyot-potasyum iyodür çözeltisi eklendi. Örnek ve körlerin absorbansları $630 \mathrm{~nm}$ de okundu. Körlerin absorbansları örneklerden çıkarılarak gerçek absorbanslar elde edilidi. a-Amilaz inhibitör aktiviteleri g özütte akarboza eşdeğer olarak hesaplandı (mmol AKAE/g). 


\section{Anti-glukozidaz aktivitesi}

Mikroplakadaki kuyucuklara $50 \mu \mathrm{l}$ örnek çözelti, $50 \mu \mathrm{l}$ glutatyon, fosfat tamponunda ( $\mathrm{pH}$ : 7.0) çözünmüş $50 \mu \mathrm{l}$ a-glukozidaz çözeltisi ve $50 \mu \mathrm{l}$ PNPG (4-p-nitrofenil-a-Dglukopiranozid) eklenerek $37^{\circ} \mathrm{C}$ de 10 dakika inkübe edildi. Benzer şekilde, $\alpha$ - glukozidaz enzim çözeltisi olmadan hazırlanmış reaksiyon reaktiflerine örnek çözeltisi eklenerek kör hazırlandı. Reaksiyon 0.2 M $50 \mu$ l sodyum karbonat konularak tamamlandı. Örnek ve körlerin absorbansları $400 \mathrm{~nm}$ de okundu. Körlerin absorbansları örneklerden çıkarılarak gerçek absorbanslar elde edilidi. $\alpha$ - Glukozidaz inhibitör aktiviteleri g özütte akarboza eşdeğer olarak hesapland 1 (mmolAKAE/g) (27).

\section{Anti-tirozinaz aktivitesi}

Tirozinaz inhibitör aktivite L-DOPA 'nın substrat olarak kullanıldığı dopakrom yöntemi ile ölçüldü. Mikroplakadaki kuyucuklara $25 \mu \mathrm{l}$ örnek çözelti, $40 \mu \mathrm{l}$ tirozinaz çözeltisi ve $100 \mu$ fosfat tamponu ( $\mathrm{pH}$ 6.8) eklendi. $\mathrm{Bu}$ karışım $25^{\circ} \mathrm{C}$ 'de 15 dakika bekletildikten sonra $40 \mu \mathrm{l}$ L-DOPA konuldu. Benzer şekilde, tirozinaz enzim çözeltisi olmadan hazırlanmış tepkime reaktiflerine örnek çözeltisi eklenerek kör hazırlandı. Örnek ve körlerin absorbansları 10 dakika oda sıcaklığında inkübe edildikten sonra $492 \mathrm{~nm}$ de okundu. Körlerin absorbansları örneklerden çıkarılarak gerçek absorbanslar elde edildi. a-Glukozidaz inhibitör aktiviteleri akarboza eşdeğer olarak hesaplandı. Körlerin absorbansları örneklerden çıkarılarak gerçek absorbanslar elde edildi. Tirozinaz inhibitör aktiviteleri g özütte kojik asite eşdeğer olarak hesaplandı (mgKAE/g) (28).

\section{Mutajenite/Antimutajenite testi}

Çalışmada kullanılmak üzere mutant Salmonella typhimurium test suşları TA98 ve TA 100 Selçuk Üniversitesi, Fen Fakültesi, Biyoloji Bölümü, Mikrobiyoloji Araştırma Laboratuvarından temin edildi. Bu suşlardan TA98 çerçeve kayması mutasyonlarını tespit ederken, TA100 suşu ise baz çifti değişimi mutasyonlarını belirlemede kullanılmaktadır. Centaureae özütlerinin toksik dozlarının belirlenmesi amacı ile Dean ve ark. (29) tarafından belirlenen yöntem kullanıldı. Özütlerin potansiyel mutajenik etkilerini belirlemek amacı ile Salmonella/mikrozom test sistemi kullanıldı. Çalışmada Maron ve Ames (30) tarafından önerilen plak inkorporasyon yöntemi uygulandı. Mililitresinde yaklaşık 1-2x $10^{9}$ bakteri içeren gecelik taze bakteri kültüründen 100 $\mu \mathrm{l}$, S9 karışımından $500 \mu \mathrm{l}$ (veya $500 \mu \mathrm{l}$ fosfat tamponu) ve son olarak farklı dozlarda bitki özütlerinden $100 \mu \mathrm{l}$ alınarak, $45^{\circ} \mathrm{C}$ 'de bekletilen $2.5 \mathrm{ml}$ hacimdeki üst agara eklendi. Kısa süreli çalkalama işleminin ardından karışım önceden hazırlanan minimal glukoz agarlı plaklara döküldü ve hızlı bir şekilde çevrilerek yüzeye yayıldı. Katılaşmanın ardindan plaklar $37^{\circ} \mathrm{C}$ de $48-72$ saat inkübe edildi (31). $\mathrm{Bu}$ sürenin sonunda plaklardaki geri dönen (revertant) koloniler sayılarak kaydedildi. Çalışma esnasında pozitif kontrol plakları olarak S9 yokluğunda TA98 suşu için 4-nitro fenilendiamin (4-NPDA) ve S9 varlığında 2-aminofloren (2AF) kullanıldı. TA100 suşu için S9 yokluğunda sodyum azid (SA) ve S9 varlığında 2-aminoantrasen (2-AA) kullanıldı. Negatif kontrol plakları olarak özütlerin çözüldügü dimetil sülfoksit içeren plaklar da hazırlandı. Sadece bakteri içeren revertant plakları da ayrıca hazırlandı. Test edilen özütlerin S. typhimurium TA 98 ve TA 100 üzerinde herhangi bir mutajenik etkisinin olabilmesi için, her özüt ile eşzamanlı olarak hazırlanan kontrol plaklarındaki (0 dozu) koloni sayısının; maksimum sayılarının iki katından fazla veya iki katına yakın değerlerde olması gerekmektedir (30).

Antimutajenite deneyinde ise iki test suşu üzerinde mutajen olduğu bilinen maddelerin, mutajenik etkilerinin bitki özütleri tarafından inhibe edilme oranları belirlenmektedir. Bu amaçla Maron ve Ames (30) tarafından önerilen ve Zengin ve ark. (8) tarafından modifiye edilmiş yöntem kullanıldı. Kısaca; $100 \mu \mathrm{l}$ bakteri kültürü ( $1-2 \times 10^{9}$ bakteri/ml), $100 \mu \mathrm{l}$ farklı dozda bitki özütü, $100 \mu$ l pozitif mutajen çözeltisi ve 500 $\mu$ l S9 karışımı ya da fosfat tamponu (S9'suz deney için), $2.5 \mathrm{ml}$ üst agar içerisine ilave edildi. Karışım vorteks ile çalkalanarak minimal glukoz agar plakalarının yüzeyine dökülerek hızlı bir şekilde yayıldı. Plaklar $37^{\circ}$ C'de $48-72$ saat inkübasyona bırakıldı ve bu sürenin ardından revertant koloniler sayıldı. İçerisinde bitki özütü olmayan ve sadece bakteri ve mutajenik madde ilave edilen plaklarda mutajenite oranı $\% 100$ (yani $\% 0$ antimutajenite) olarak belirlendi. Özütlerin antimutajenite oranları ise $[(\mathrm{A}-\mathrm{B}) /(\mathrm{A}-\mathrm{C})] \mathrm{x} 100$ formülü ile hesaplandı. $\mathrm{Bu}$ formülde $\mathrm{A}=$ Bakteri+mutajen plağındaki revertant koloni sayısı; $\mathrm{B}=$ Bakteri+mutajen+özüt plağındaki revertant koloni sayısı; $\mathrm{C}=$ Kendiliğinden geri dönen revertant koloni sayısını (sadece bakteri plağı) ifade etmektedir (10). Buradan elde edilen sonuçlara göre \% 0-25 aralığındaki inhibisyon: zayıf antimutajenite veya aktivite yok; \%26-40 aralığındaki inhibisyon: orta dereceli antimutajenite; $\% 40$ ve üzeri inhibisyon: güçlü antimutajenite olarak belirlendi (32).

\section{İstatistik değerlendirme}

Bütün testler üç tekrarlı deneyler yapılarak gerçekleştirildi ve sonuçlar üç tekrarlı deneylerin ortalaması ve standart 
sapması olarak verildi. Sonuçlar arasındaki anlamlılık testleri SPSS v22. programı kullanılarak ANOVA varyans analizi yardımıyla $\% 95$ güven aralığı seçilmek suretiyle $(\alpha=0.05)$ Tukey testiyle belirlendi.

\section{BULGULAR VE TARTIŞMA}

\section{Antioksidan kapasite}

Bitkilerin antioksidan kapasitelerinin değerlendirilmesi üzerine çok sayıda çalışma yapılmasına karşılık antioksidan kapasiteyi tümüyle yansitan tek bir metot geliştirilememiştir. $\mathrm{Bu}$ nedenle farklı kimyasal test sistemleri kullanılarak antioksidan kapasitenin tümüyle yorumlanması gerekmektedir. $\mathrm{Bu}$ noktadan hareketle çalışmamızda farklı antioksidan test sistemleri kullanılmış ve her bir özüt için ayrıca toplam fenolik ve flavonoid içerik hesaplanmıştır.

Çalışlan özütlerin toplam fenolik ve flavonoid içerikleri sırasıyla Folin ve $\mathrm{AlCl}_{3}$ metotları kullanılarak belirlenmiştir. Toplam fenolik ve flavonoid içerik bakımından en zengin özüt olarak metanol özütü belirlenmiş ve bunu sırasıyla etil asetat ile su özütü takip etmektedir (Tablo 1). Çalışmamızı doğrular nitelikte birçok çalışmada da metanol özütü fenolik içerik bakımından en zengin özüt olarak nitelendirilmiştir $(33,34)$. Centaurea üyeleri üzerine yapılan çeşitli çalışmalarda toplam fenolik içerik rapor edilmiştir (35-37).

Tablo 1. C. pterocaula özütlerinin toplam fenolik ve flavonoid içerikleri ile DPPH radikal giderme aktivitesi

\begin{tabular}{llll}
\hline Özütler & $\begin{array}{l}\text { Toplam fenolik } \\
\text { içerik (mgGA- } \\
\text { E/g özüt) }\end{array}$ & $\begin{array}{l}\text { Toplam flavono- } \\
\text { id içerik (mg- } \\
\text { RE/g özüt) }\end{array}$ & $\begin{array}{l}\text { DPPH radikal gi- } \\
\text { derme aktivitesi } \\
\text { (mgTE/g özüt) }\end{array}$ \\
\hline $\begin{array}{l}\text { Etil } \\
\text { asetat }\end{array}$ & $22.47 \pm 0.10 \mathrm{~b}^{*}$ & $20.62 \pm 0.12 \mathrm{~b}$ & $13.93 \pm 0.95 \mathrm{c}$ \\
& & & \\
Metanol & $25.22 \pm 0.20 \mathrm{a}$ & $31.14 \pm 0.34 \mathrm{a}$ & $31.06 \pm 0.72 \mathrm{a}$ \\
& & & \\
Su & $15.77 \pm 0.15 \mathrm{c}$ & $0.67 \pm 0.02 \mathrm{c}$ & $18.35 \pm 0.70 \mathrm{~b}$ \\
& & & \\
\hline
\end{tabular}

* Üç paralel ölçümün ortalamasııstandart sapma. GAE: gallik asit eşdeğeri; RE: rutin eşdeğeri; TE: trolox eşdeğeri; ${ }^{a b c}$ Aynı sütundaki farklı harfe sahip gruplar arasındaki fark istatistiki olarak önemlidir (ANOVA, Tukey HSD, p <0.05).
Bitkilerin antioksidan kapasitelerinin değerlendirildiği çalışmalarda en az bir serbest radikal kullanılarak bu radikalin bitki özütü tarafından ne oranda giderildiği hesaplanmaktadır. Bu radikaller içerisinde en yaygın olanı DPPH'dir. Stabil bir radikal olan DPPH mor renklidir ve antioksidan moleküllerden bir elektron alarak sar1 pikrilhidrazil formuna dönmektedir. $\mathrm{Bu}$ dönüşüm spektrofotometrik olarak 515-517 nm’de takip edilmektedir. Çalışmamızda C. pterocaula özütlerinin DPPH giderme kapasiteleri araştırılmış ve Tablo l'de sunulmuştur. Serbest radikal giderimi bakımından en zengin özüt $31.06 \mathrm{mgTE} / \mathrm{g}$ özüt ile metanol özütüdür. Bununla birlikte su ve etil asetat özütleri için bu değer 18.35 ve 13.93 mgTE/g özüt olarak bulunmuştur. Metanol özütünde gözlenen bu güçlü aktivite fenoliklerin yüksek seviyeleri ile açıklanabilir ve bu durum çeşitli çalışmalarda da rapor edilmiştir $(38,39)$. Centaurea üyelerinin serbest radikal giderme (süpürme) etkinliği üzerine çeşitli çalışmalarda rapor edilmiştir (40-42) ve bu çalışmalarda genellikle yarısının süpürüldüğü konsantrasyon $\mathrm{IC}_{50}$ hesaplanmıştır. Bu bağlamda çalışmamızın sonuçlarını önceki raporlarla karşılaştırmak olanaksızdır.

İndirgemegücüantioksidankapasitenin değerlendirilmesinde önemli bir indikatör olarak düşünülmektedir ve bu anlamda çalışmamızda CUPRAC ve FRAP testleri uygulanmıştır. Çalışılan özütlerin indirgeme güçlerine bakıldığında her iki test sisteminde de metanolün en güçlü aktiviteye sahip olduğu görülmektedir (Tablo 2). Bu durum özütteki fenoliklerin yüksek seviyesi ile açıklanabilir. Fosfomolibdat testi asidik ortamda antioksidan bileşikleri $\mathrm{Mo}^{6+}$ yi $\mathrm{Mo}^{5+}$ ya indirgemesine ve bu durumun $695 \mathrm{~nm}$ 'de izlenmesine dayanır. FRAP ve CUPRAC testlerine benzer şekilde fosfomolibdat testinde de metanol özütü en güçlü aktiviteyi sergilemiştir.

Geçiş metalleri lipid peroksidasyonunda bir katalizör olarak görev almakta ve dolasıly bunların etkisiz hale getirilmesi önemli bir antioksidan mekanizma olarak kabul edilmektedir. $\mathrm{Bu}$ bağlamda $C$. pterocaula özütlerinin metal şelatlama yetenekleri ferrozin test sistemi kullanılarak belirlenmiştir (Tablo 2). Çalışllan özütlerden su özütü en güçlü metal şelatlama yeteneğine sahiptir. Bununla birlikte metanol özütü en zayıf şelatlama aktivitesi sergilemiştir. Bu durum diğer antioksidan test sistemleri ile farklılık göstermektedir. Bu durum su özütünde fenolikler dışındaki diğer şelatlayıcı ajanların varlı̆̆ı ile açıklanabilir. Benzer sonuçlar çeşitli bitki özütleri içinde rapor edilmiştir $(43,44)$. Literatür taraması yapıldığında çeşitli Centaurea türleri için metal şelatlama özelliğinin rapor edildiği görülmüştür $(35,45)$. 
Tablo 2. C. pterocaula özütlerinin indirgeme gücü, metal şelatlama ve fosfomolibdenum aktiviteleri

\begin{tabular}{lllll}
\hline Özütler & $\begin{array}{l}\text { CUPRAC } \\
\text { (mgTE/g } \\
\text { özüt) }\end{array}$ & $\begin{array}{l}\text { FRAP (mg- } \\
\text { TE/g özüt) }\end{array}$ & $\begin{array}{l}\text { Metal } \\
\text { Selatlama } \\
\text { (mgEDTA- } \\
\text { E/g özüt) }\end{array}$ & \begin{tabular}{l}
$\begin{array}{l}\text { Fosfomo- } \\
\text { libdenum } \\
\text { (mmolTE/g } \\
\text { özüt) }\end{array}$ \\
\hline $\begin{array}{l}\text { Etil } \\
\text { asetat }\end{array}$
\end{tabular} \\
$\begin{array}{lllll}\text { Meta- } \\
\text { nol }\end{array}$ & $66.48 \pm 0.53 \mathrm{~b}^{*}$ & $32.71 \pm 0.31 \mathrm{c}$ & $17.88 \pm 0.81 \mathrm{~b}$ & $1.92 \pm 0.11 \mathrm{a}$ \\
& & $51.03 \pm 0.86 \mathrm{a}$ & $15.47 \pm 0.34 \mathrm{c}$ & $2.11 \pm 0.12 \mathrm{a}$ \\
Su & $45.37 \pm 0.37 \mathrm{c}$ & $43.12 \pm 1.12 \mathrm{~b}$ & $21.27 \pm 0.08 \mathrm{a}$ & $0.74 \pm 0.03 \mathrm{~b}$ \\
\hline
\end{tabular}

* Üç paralel ölçümün ortalamasııstandart sapma. EDTAE: EDTA eşdeğeri; TE: trolox eşdeğer, abc Aynı sütundaki farklı harfe sahip gruplar arasındaki fark istatistiki olarak önemlidir (ANOVA, Tukey HSD, $\mathrm{p}<0.05)$.

\section{Enzim inhibitör potansiyeli}

Günümüzde birçok faktöre bağlı olarak çeşitli hastalıklar küresel boyuta ulaşmıştır. Bunların başında Alzheimer hastalı̆ğ ve diyabet gelmektedir. Bu hastalıkların görülme oranı son yıllarda önemli artışlar göstermiştir. Örneğin, Amerika'da her 67 saniyede bir kişi Alzheimer'a yakalanmakta ve bu durumun 2050'de 33 saniyeye düşmesi beklenmektedir (46). Ayrıca, günümüzde 366 milyon insan diabetten etkilenirken bu sayının 2050'de 552 milyona yükselmesi beklenmektedir (47). Bu bağlamda bu hastalıkların tedavisine yönelik yeni stratejilerin ortaya konulması büyük önem arz etmektedir. Bu stratejiler arasında en çok kabul göreni anahtar enzimlerin inhibisyonudur. Bu teoriye göre hastalıkların patolojisinde rol oynayan anahtar enzimler inhibe edilerek hastalıktan kaynaklanacak semptomların hafifletilmesi sağlanır. Örneğin, asetilkolinesteraz sinaptik boşlukta asetil ve kolinin parçalanmasını katalize eder. Alzheimer hastalarında bu enzimin inhibe edilmesi ile bilinçsel fonksiyonların artırılması sağlanır ve bu durum kolinerjik hipotez olarak isimlendirilir (48). a-Amilaz ve $a$-glukozidaz enzimleri şeker metabolizmasinın temel enzimleri olup bunların faaliyeti sonucu kan glukoz seviyesi yükselmektedir. $\mathrm{Bu}$ anlamda, bu enzimlerin inhibe edilmesi diyabette kan glukoz seviyesinin kontrolünde önemli bir mekanizmadır (49). Yine tirozinaz enzimi melanin sentezinin en önemli enzimidir ve bu enzimin inhibe edilmesi deri hastalıklarının kontrolünde temel yoldur (50). Bu bağlamda çok çeşitli enzim inhibitörleri (kolinesteraz için galantamin, amilaz ve glukozidaz için akarboz, tirozinaz için kojik asit) sentetik olarak üretilmiştir. Bununla birlikte bu sentetik inhibitörlerin sindirim sistemi bozukluklara yol açması ve hepatotoksik özellikleri bunların kullanımlarını kaygılı hale getirmiştir (51-53). Bu noktadan hareketle bitkisel kaynaklı doğal inhibitörlere olan ilgi her geçen gün artmaktadır.

Çalışmamızın kapsamında C. pterocaula özütlerinin enzim inhibisyon kapasiteleri spektrofotometrik metotlarla araştırılmış ve sonuçlar Tablo 3' de verilmiştir. Çalışılan özütlerin kolinesteraz inhibisyon aktiviteleri karşılaştırıldığında, etil asetat ve metanol özütleri asetilkolinesteraz üzerine benzer etkinlik sergilemiştir. Bununla birlikte yalnızca etil asetat özütü butirilkolinesteraz üzerine aktiftir. Tirozinaz inhibisyonuna bakıldğında yine etil asetat ve methanol özütlerinde inhibisyon aktivitesi gözlenirken su özütü tirozinaz üzerine etkili değildir. Amilaz inhibisyonu bakımından en güçlü özüt etil asetat iken glukozidaz üzerine en etkin özüt metanoldür. Genel itibariyle su özütü enzim inhibisyonları bakımından en zayıf özüt olarak tespit edilmiştir. Centaurea üyelerinin enzim inhibisyonları üzerine çeşitli çalışmalar olmasına karşıllık (35, 54, 55), C. pterocaula için herhangi bir veri bulunmamaktadır.

Tablo 3. C. pterocaula özütlerinin enzim inhibitör potansiyelleri

\begin{tabular}{llllll}
\hline Özütler & $\begin{array}{l}\text { AChE } \\
\text { İnhibisyonu } \\
\text { (mgGALA- } \\
\text { E/g özüt) }\end{array}$ & $\begin{array}{l}\text { BChE } \\
\text { İnhibisyonu } \\
\text { (mgGALA- } \\
\text { E/g özüt) }\end{array}$ & $\begin{array}{l}\text { Tirozinaz } \\
\text { İnibisyonu } \\
\text { özüt) }\end{array}$ & $\begin{array}{l}\text { Amilaz } \\
\text { İnhibisyonu } \\
\text { (mmo- } \\
\text { 1ACAE/g } \\
\text { özüt) }\end{array}$ & $\begin{array}{l}\text { Glukozidaz } \\
\text { Inhibisyo- } \\
\text { nu (mmo- } \\
\text { 1ACAE/g } \\
\text { özüt) }\end{array}$ \\
\hline $\begin{array}{l}\text { Etil } \\
\text { asetat }\end{array}$ & $1.87 \pm 0.01 \mathrm{a}^{*}$ & $1.07 \pm 0.01$ & $56.72 \pm 0.15 \mathrm{a}$ & $1.13 \pm 0.01 \mathrm{a}$ & $0.66 \pm 0.01 \mathrm{~b}$ \\
Metanol & $1.87 \pm 0.01 \mathrm{a}$ & - & $35.45 \pm 0.08 \mathrm{~b}$ & $0.59 \pm 0.01 \mathrm{~b}$ & $0.92 \pm 0.01 \mathrm{a}$ \\
Su & - & - & - & $0.14 \pm 0.01 \mathrm{c}$ & $0.57 \pm 0.01 \mathrm{c}$ \\
\hline
\end{tabular}

* Üç paralel ölçümün ortalamasııstandart sapma. GALAE: galatamin eşdeğeri; KAE: kojik asit eşdeğer; ACAE: akarboz eşdeğeri; - aktivite yok. ${ }^{\text {abc }}$ Aynı sütundaki farklı harfe sahip gruplar arasındaki fark istatistiki olarak önemlidir (ANOVA, Tukey HSD, $\mathrm{p}<0.05)$.

\section{Mutajenik/Antimutajenik özellikler}

Tablo 4' de görüldüğü üzere mutajenite deneyi sonucu elde edilen tüm revertant koloni sayıları mutajenite limitlerine ulaşmadı. Diğer bir ifade ile Centaurea özütleri revertant koloni sayılarını, normalin iki katına yakın ya da iki katından fazla bir sayıya ulaştıracak bir etki göstermedi. Bu durumda Centaurea özütleri S9 varlığında ve yokluğunda yapılan Ames testi sonuçlarına göre TA98 ve TA100 suşları üzerinde mutajenik bulunmadı (Tablo 4). 
Tablo 4. C. pterocaula özütlerinin S9 varlığında ve yokluğunda S. typhimurium TA98 ve TA100 suşları üzerindeki mutajenik aktiviteleri

\begin{tabular}{|c|c|c|c|c|c|}
\hline & \multirow[t]{3}{*}{ Konsantrasyon $(\mu \mathrm{g} / \mathrm{plak})$} & \multicolumn{4}{|c|}{ His $^{+}$revertant sayları (revertant/plak) } \\
\hline & & \multicolumn{2}{|c|}{ TA 98} & \multicolumn{2}{|c|}{ TA 100} \\
\hline & & S9 (-) & S9 (+) & S9 (-) & S9 (+) \\
\hline${ }^{\star}$ Negatif kontrol & $100 \mu \mathrm{l} /$ plak & $28 \pm 2 \mathrm{a}$ & $35 \pm 6 a$ & $113 \pm 6 a$ & $120 \pm 6 \mathrm{a}$ \\
\hline Pozitif kontrol & & $513 \pm 81 \mathrm{~b}$ & $4560 \pm 164 \mathrm{~b}$ & $4642 \pm 132 b$ & $4876 \pm 175 b$ \\
\hline \multirow{3}{*}{ Centaurea etil asetat } & 0 & $36 \pm 5 a$ & $41 \pm 4 a$ & $154 \pm 10 \mathrm{ac}$ & $165 \pm 8 c$ \\
\hline & 5000 & $35 \pm 3 a$ & $44 \pm 4 a$ & $156 \pm 1 \mathrm{c}$ & $138 \pm 10 \mathrm{a}$ \\
\hline & 1000 & $40 \pm 2 a$ & $38 \pm 5 a$ & $144 \pm 12 \mathrm{a}$ & $153 \pm 13 \mathrm{ac}$ \\
\hline \multirow{5}{*}{ Centaurea metanol } & 500 & $38 \pm 3 a$ & $41 \pm 3 a$ & $109 \pm 2 \mathrm{a}$ & $143 \pm 16 \mathrm{a}$ \\
\hline & 0 & $36 \pm 5 a$ & $41 \pm 4 \mathrm{a}$ & $154 \pm 10$ ac & $165 \pm 8 c$ \\
\hline & 5000 & $28 \pm 9 a$ & $35 \pm 5 a$ & $123 \pm 38 \mathrm{ac}$ & $142 \pm 11$ ac \\
\hline & 1000 & $44 \pm 2 \mathrm{ac}$ & $39 \pm 6 a$ & $132 \pm 21 \mathrm{ac}$ & $137 \pm 16 \mathrm{a}$ \\
\hline & 500 & $51 \pm 2 c$ & $44 \pm 3 a$ & $171 \pm 36 c$ & $154 \pm 9 \mathrm{ac}$ \\
\hline \multirow{4}{*}{ Centaurea su } & 0 & $36 \pm 5 a$ & $41 \pm 4 a$ & $154 \pm 10 \mathrm{ac}$ & $165 \pm 8 c$ \\
\hline & 5000 & $34 \pm 2 \mathrm{a}$ & $39 \pm 5 a$ & $141 \pm 3 a$ & $145 \pm 23 a$ \\
\hline & 1000 & $49 \pm 5 \mathrm{ad}$ & $45 \pm 4 a$ & $160 \pm 14 \mathrm{ac}$ & $158 \pm 19 \mathrm{ac}$ \\
\hline & 500 & $42 \pm 1$ ad & $40 \pm 6 a$ & $118 \pm 20 \mathrm{a}$ & $147 \pm 22 \mathrm{ac}$ \\
\hline
\end{tabular}

* Negatif kontrol: DMSO (100 $\mu \mathrm{l} /$ plak) S. typhimurium TA98 ve TA100 suşları için S9 varlığında ve yokluğunda negatif kontrol olarak kullanild.

'Pozitif kontroller:

2-Aminofloren (7.5 $\mu \mathrm{g} / \mathrm{plak})$ TA98 suşu için S9 varlığında pozitif indirek mutajen olarak kullanıldı; 4-nitro-O-fenilendiamin (5 $\mu \mathrm{g} / \mathrm{plate})$ TA98 suşu için S9 yokluğunda pozitif direk mutajen olarak kullanıldı.

2-Aminoanthracene ( $5 \mu \mathrm{g} /$ plate) TA100 suşu için S9 varlığında pozitif indirek mutajen olarak kullanıldı; Sodium azid ( $5 \mu \mathrm{g} / \mathrm{plate})$ TA100 suşu için S9 yokluğunda pozitif direk mutajen olarak kullanıldı.

abc Aynı sütundaki farklı harfe sahip gruplar arasındaki fark istatistiki olarak önemlidir (ANOVA, Tukey HSD, p<0.05).

Antimutajenite açısından değerlendirildiğinde; Centaurea su özütlerinin TA98 suşu üzerinde S9 karışımı yokluğunda 4-NPDA'ya karş1 $\% 40$ 'ın üzerindeve $\%$ 82'lere ulaşan oranlarda inhibisyon ortaya koyduğu dolayısı ile güçlü antimutajenik olduğu belirlendi (Tablo 5). Metanol özütünün 5000 ve 1000 $\mu \mathrm{g} /$ plak dozlarında $\% 49$ ve $\% 44$ inhisiyon oranları ile güçlü antimutajenik olmasına rağmen, etil asetat öztününün tüm konsantrasyonlarda orta dereceli antimutajenik olduğu (\%28, \%26, \%26) tespit edildi. S9 karışımı varllğıında ise etil asetat ve metanol özütleri 2-AF’ye karşı $5000 \mu \mathrm{g}$ /plak dozlarda çok güçlü (sırası ile \%92 ve \%92) antimutajenik aktivite ortaya koydu. Buna rağmen su özütü sadece $5000 \mu \mathrm{g} / \mathrm{plak}$ dozunda orta dereceli antimutajenik olarak belirlendi (\%39 inhibisyon) (Tablo 5). Su özütünün TA100 suşu üzerinde S9 karışımı yokluğunda SA’ya karşı sırası ile \%58, \%58 ve \%61 inhibisyon oranları ile güçlü antimutajenik aktiviteye sahip olduğu görüldü. Etil asetat özütü SA’ya karşı $5000 \mu \mathrm{g} /$ plak dozunda S9 yokluğunda \%46 inhibisyon oranı ile güçlü antimutajenik olarak belirlenmesine rağmen, aynı dozda metanol özütü \%30 inhibisyon ile orta dereceli antimutajenite gösterdi. S9 karışımının ilavesi ile metanol ve etil asetat özütlerinin inhibisyon oranlarının yükseldiği görüldü. 2-AA’ya karşı bu oranlar $5000 \mu \mathrm{g} /$ plak dozunda etil asetat için \%91 ve metanol için \%87 olarak tespit edildi. Aynı zamanda etil asetat özütü $1000 \mu \mathrm{g} /$ plak dozunda da \% 68 inhibisyon oranına yükselerek güçlü antimutajenik aktiviteye sahip olduğunu gösterdi. Su özütlerinde ise hem TA98 hem de TA100 suşları üzerinde S9 karışımı ilavesi, S9 yokluğunda elde edilen inhibisyon oranlarını oldukça düşürerek 2-AF ve 2-AA'ya karşı zayıf antimutajenik olarak değerlendirilmelerine sebep oldu. Sonuç olarak C. pterocaula özütlerinin, baz çifti değişimi ve çerçeve kayması mutasyonlarını tetikleyen mutajenlere karşı önemli oranda inhibisyona yani antimutajenik aktiviteye sahip oldukları Salmonella/mikrozom testi (Ames testi) ile ortaya kondu. 
Tablo 5. C. pterocaula özütlerinin $S 9$ varlığında ve yokluğunda S. typhimurium TA98 ve TA100 suşları üzerinde, mutajen maddelere karşı belirlenen revertant koloni sayıları ve inhibisyon oranları

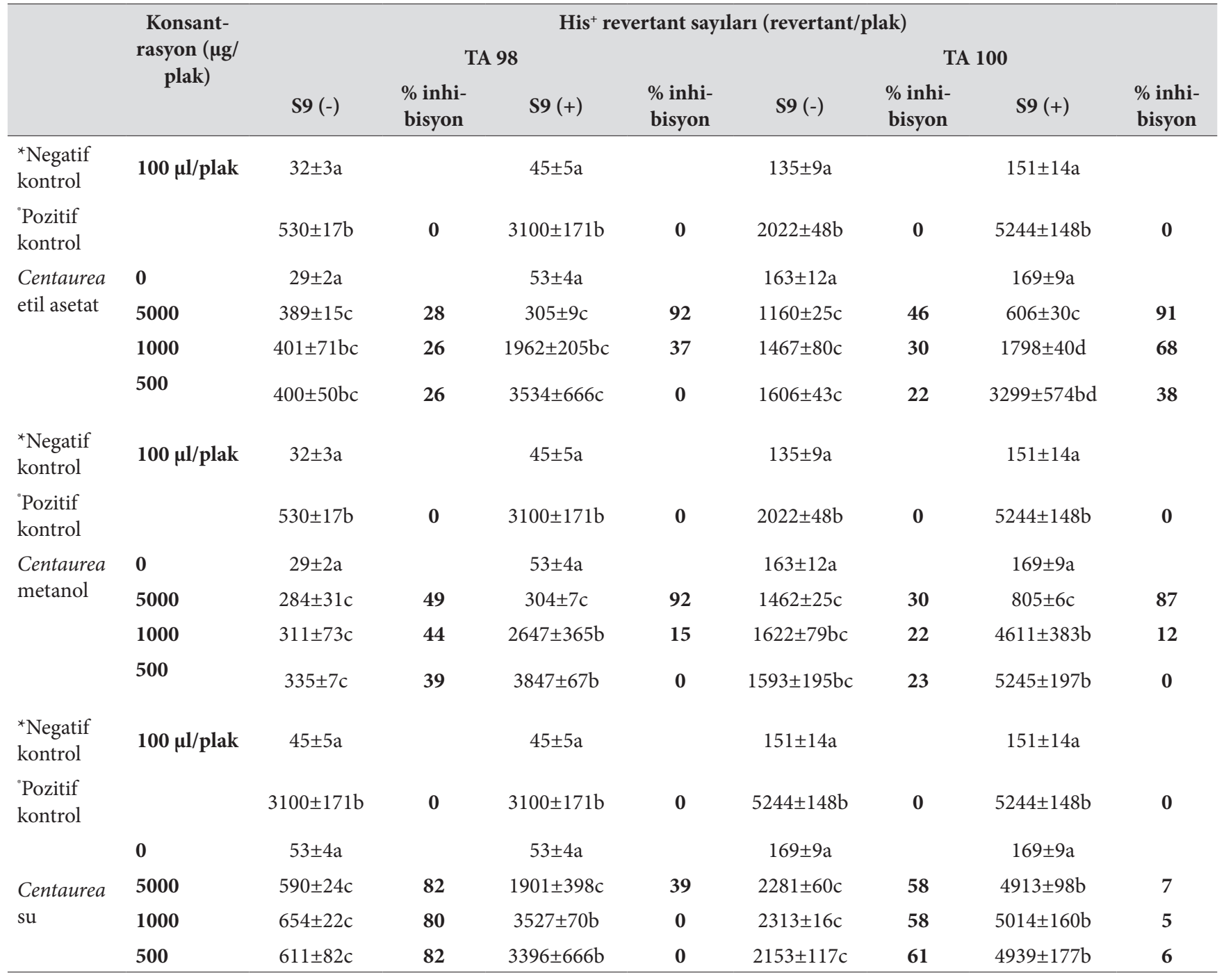

* Negatif kontrol: DMSO (100 $\mu$ l/plak) S. typhimurium TA98 ve TA100 suşları için S9 varlığında ve yokluğunda negatif kontrol olarak kullanild.

'Pozitif kontroller:

2-Aminofloren (7.5 $\mu \mathrm{g} / \mathrm{plak})$ TA98 suşu için S9 varlığında pozitif indirek mutajen olarak kullanıldı; 4-nitro-O-fenilendiamin (5 $\mu \mathrm{g} / \mathrm{plak})$ TA98 suşu için S9 yokluğunda pozitif direk mutajen olarak kullanıldı.

2-Aminoanthracene ( $5 \mu \mathrm{g} / \mathrm{plak}$ ) TA100 suşu için S9 varlığında pozitif indirek mutajen olarak kullanıldı; Sodium azid (5 $\mu \mathrm{g} / \mathrm{plak})$ TA100 suşu için S9 yokluğunda pozitif direk mutajen olarak kullanıldı.

abcd Aynı sütundaki farklı harfe sahip gruplar arasındaki fark istatistiki olarak önemlidir (ANOVA, Tukey HSD, p<0.05).

\section{SONUÇ}

Günümüzde değişen hayat şartları ve beslenme alışkanlıklarına bağlı olarak kronik ve dejeneratif hastalıklara yakalanma riski her geçen gün artış göstermektedir. $\mathrm{Bu}$ noktadan hareketle, bu durumun minimize edilmesi bilim dünyasının ana konularından biridir. Bu bağlamda, bitkiler ve onların sergiledikleri biyolojik aktiviteler, yeni ilaç ve gıda formülasyonlarının geliştirilmesinde oldukça yararlı bir havuz olarak görülmektedir. Bu temelde gerçekleştirdiğimiz çalışmamızın sonucunda, etil asetat ile metanol özütü etkin antioksidan, enzim inhibitör ve antimutajenik etkiler sergilemiştir. Güvenli ve etkin fonksiyonel ajanların tespitinin önemli olduğu günümüzde, Centaurea pterocaula doğal ajanların önemli bir kaynă̆ı olarak düşünülebilir. 
Screening for antioxidant and antimutagenic properties of extracts from Centaurea pterocaula as well as their enzyme inhibitory potentials

\section{ABSTRACT}

The purpose of this study was to evaluate the antioxidant capacities, mutagenic/antimutagenic propeties and enzyme inhibitory effects of three extracts (ethyl acetate, methanol and water) of Centaurea pterocaula. The antioxidant properties were investigated using in vitro antioxidant methods such as radical scavenging (DPPH assay), reducing power (FRAP and CUPRAC assays), phosphomolybdenum and metal chelating activity. Enzyme inhibitory effects were tested aganist cholinesterase, tyrosinase, amylase and glucosidase. Ames test was used to show mutagenic/antimutagenic properties of these extracts. Methanol extract had the strongest free radical scavenging $(31.06 \mathrm{mgTE} / \mathrm{g}$ extract) and reducing power abilities $(66.95 \mathrm{mgTE} / \mathrm{g}$ extract for CUPRAC and $51.03 \mathrm{mgTE} / \mathrm{g}$ extract for FRAP). Also, ethyl acetate extract exhibited the strongest effect on the tested enzymes (except for glucosidase). Total phenolic and flavonoid contents were found to be 15.77-25.22 mg GAE/g extract and 0.67-31.44 mg RE/g extract, respectively. The mutagenicity was not seen for all extracts tested, while it was determined that some samples had significant antimutagenicity. In the condition of presence of S9 mix, ethyl acetate and methanol extracts revealed excellent antimutagenic activity (92\% and 92\%) at a dose of $5000 \mu \mathrm{g} /$ plate against 2-aminoflourene (2-AF) for TA98 strain. According to the results of the present study, C. pterocaula can be considered as a potential source for developing new nutraceuticals or pharmaceuticals.

Keywords: Centaurea pterocaula, antioxidant, enzyme inhibition, antimutagenic, natural agents.

\section{KAYNAKLAR}

1. Larsson SC, Virtamo J, Wolk A. Total and specific fruit and vegetable consumption and risk of stroke: A prospective study. Atherosclerosis 2013; 227: 147-52.

2. Malta LG, Tessaro EP, Eberlin M, Pastore GM, Liu RH. Assessment of antioxidant and antiproliferative activities and the identification of phenolic compounds of exotic Brazilian fruits. Food Res Int 2013; 53: 417-25.

3. Ramos B, Miller FA, Brandao TRS, Teixeira P, Silva CLM. Fresh fruits and vegetables-An overview on applied methodologies to improve its quality and safety. Innov Food Sci Emerg 2013; 20: 1-15.

4. Spencer JPE, Mohsen MMA, Minihane AM, Mathers JC. Biomarkers of the intake of dietary polyphenols: strengths, limitations and application in nutrition research. Brit J Nutr 2008; 99: 12-22.

5. Beecher GR. Overview of dietary flavonoids: nomenclature, occurrence and intake. J Nutr 2003; 133: 3248S-54S.

6. Cook NC, Samman S. Flavonoids - Chemistry, metabolism, cardioprotective effects, and dietary sources. J Nutr Biochem 1996; 7: 66-76.

7. Liu Q, Cai WS, Shao XG. Determination of seven polyphenols in water by high performance liquid chromatography combined with preconcentration. Talanta 2008; 77: 679-83.

8. Zengin G, Uysal A, Gunes E, Aktumsek A. Survey of Phytochemical Composition and Biological Effects of Three Extracts from a Wild Plant (Cotoneaster nummularia Fisch et Mey.): A Potential Source for Functional Food Ingredients and Drug Formulations. Plos One 2014; 9: 1-13.

9. Akin D, Durak Y, Uysal A, Gunes E, Aladag MO. Assessment of Antimutagenic Action of Celtis glabrata Steven ex Planch. (Cannabaceae) Extracts Against Base Pair Exchange and Frame Shift Mutations on Salmonella typhimurium TA98 and TA100 Strains by Ames Test. Drug Chem Toxicol 2016; 39: 312-21.
10. Uysal A, Gunes E, Sarikurkcu C, Celik H, Durak Y, Uren MC. New Prospective Materials for Chemoprevention: Three Phlomis. Brit J Pharm Res 2016; 10:1-13.

11. Baser KHC. Aromatic biodiversity among the flowering plant taxa of Turkey. Pure Appl Chem 2002; 74: 527-45.

12. Clapman A, Tutin T, Warburg W. The flora of the British Isles. Cambridge Uni-versity Press, Cambridge, UK. 1952.

13. Davis PH. Flora of Turkey and the east Aegean islands: Edinburgh University Press. 1965.

14. Sezik E, Yesilada E, Honda G, Takaishi Y, Takeda Y, Tanaka T. Traditional medicine in Turkey X. Folk medicine in Central Anatolia. J Ethnopharmacol 2001; 75: 95-115.

15. Grieve M. A Modern Herbal 2002. Available from: http:// botanical.com/botanical/mgmh/c/centau46.html.

16. Sarker SD, Savchenko T, Whiting P, Sik V, Dinan LN. Moschamine, cis-moschamine, moschamindole and moschamindolol: Four novel indole alkaloids from Centaurea moschata. Nat Prod Lett 1997; 9: 189-99.

17. Reyhan A, Küpeli E, Ergun F. The biological activity of Centaurea L. species. Gazi University J Sci 2004; 17: 149-64.

18. Tekeli Y, Sezgin M, Aydın Ş. Konya'da Yetişen Centaurea pterocaula Truatv.'ın Fenolik Yapısı ve Antioksidan Etkisi. SDÜ Fen Edebiyat Fakültesi Fen Dergisi 2008; 35-41.

19. Slinkard K, Singleton VL. Total phenol analysis: automation and comparison with manual methods. Am J Enol Vitic 1977; 28: 49-55.

20. Berk S, Tepe B, Arslan S, Sarikurkcu C. Screening of the antioxidant, antimicrobial and DNA damage protection potentials of the aqueous extract of Asplenium ceterach DC. Afr J Biotechnol 2011; 10: 8902-8.

21. Sarikurkcu C. Antioxidant activities of solvent extracts from endemic Cyclamen mirabile Hildebr. tubers and leaves. Afr J Biotechnol 2013; 10: 831-9.

22. Benzie IFF, Strain JJ. The ferric reducing ability of plasma (FRAP) as a measure of "antioxidant power": The FRAP assay. 
Anal Biochem 1996; 239: 70-6.

23. Apak R, Guclu K, Ozyurek M, Karademir SE, Ercag E. The cupric ion reducing antioxidant capacity and polyphenolic content of some herbal teas. Int J Food Sci Nutr 2006; 57: 292304.

24. Prieto P, Pineda M, Aguilar M. Spectrophotometric quantitation of antioxidant capacity through the formation of a phosphomolybdenum complex: specific application to the determination of vitamin E. Anal Biochem 1999; 269: 337-41.

25. Dinis TCP, Madeira VMC, Almeida LM. Action of Phenolic Derivatives (Acetaminophen, Salicylate, and 5-Aminosalicylate) as Inhibitors of Membrane LipidPeroxidation and as Peroxyl Radical Scavengers. Arch Biochem and Biophys 1994; 315: 161-9.

26. Ellman GL, Courtney KD, Andres V, Jr., Feather-Stone RM. A new and rapid colorimetric determination of acetylcholinesterase activity. Biochem Pharmacol 1961; 7: 8895.

27. Palanisamy UD, Ling LT, Manaharan T, Appleton D. Rapid isolation of geraniin from Nephelium lappaceum rind waste and its anti-hyperglycemic activity. Food Chem 2011; 127: 217.

28. Orhan IE, Senol FS, Gulpinar AR, Sekeroglu N, Kartal M, Sener B. Neuroprotective potential of some terebinth coffee brands and the unprocessed fruits of Pistacia terebinthus L. and their fatty and essential oil analyses. Food Chem 2012; 130: 882-8.

29. Dean BJ, Brooks TM, Hodsonwalker G, Hutson DH. Genetic Toxicology Testing of 41 Industrial-Chemicals. Mutat Res 1985; 153: 57-77.

30. Maron DM, Ames BN. Revised Methods for the Salmonella Mutagenicity Test. Mutat Res 1983; 113: 173-215.

31. Uysal A, Lazarova I, Zengin G, Gunes E, Aktumsek A, Gevrenova R. New Perspectives on Asphodeline lutea from Bulgaria and Turkey: Anti-mutagenic, Anti-microbial and Anti-methicillin Resistant Staphylococcus aureus (MRSA) Activity. Brit J Pharm Res 2016; 10.

32. Negi PS, Jayaprakasha GK, Jena BS. Antioxidant and antimutagenic activities of pomegranate peel extracts. Food Chem 2003; 80: 393-7.

33. Šamec D, Valek-Žulj L, Martinez S, Grúz J, Piljac A, PiljacŽegarac J. Phenolic acids significantly contribute to antioxidant potency of Gynostemma pentaphyllum aqueous and methanol extracts. Ind Crop Prod 2016; 84: 104-7.

34. Yasir M, Sultana B, Nigam PS, Owusu-Apenten R. Antioxidant and genoprotective activity of selected cucurbitaceae seed extracts and LC-ESIMS/MS identification of phenolic components. Food Chem 2016; 199: 307-13.

35. Aktumsek A, Zengin G, Guler GO, Cakmak YS, Duran A. Antioxidant potentials and anticholinesterase activities of methanolic and aqueous extracts of three endemic Centaurea L. species. Food Chem Toxicol 2013; 55: 290-6.

36. Zengin G, Cakmak YS, Guler GO, Aktumsek A. In vitro antioxidant capacities and fatty acid compositions of three Centaurea species collected from Central Anatolia region of Turkey. Food Chem Toxicol 2010; 48: 2638-41.

37. Zengin G, Guler GO, Cakmak YS, Aktumsek A. Antioxidant capacity and fatty acid profile of Centaurea kotschyi (Boiss.
\& Heldr.) Hayek var. persica (Boiss.) Wagenitz from Turkey. Grasas Y Aceites 2011; 62: 90-5.

38. Akkari H, Hajaji S, B'chir F, Rekik M, Gharbi M. Correlation of polyphenolic content with radical-scavenging capacity and anthelmintic effects of Rubus ulmifolius (Rosaceae) against Haemonchus contortus. Vet Parasitol 2016; 221: 46-53.

39. Kolniak-Ostek J. Chemical composition and antioxidant capacity of different anatomical parts of pear (Pyrus communis L.). Food Chem 2016; 203: 491-7.

40. Tekeli Y, Sezgin M, Aktumsek A. Antioxidant property of Centaurea solstitialis L. from Konya, Turkey. Asian J Chem 2008; 20: 4831-5.

41. Tepe B, Sokmen M, Akpulat HA, Yumrutas O, Sokmen A. Screening of antioxidative properties of the methanolic extracts of Pelargonium endlicherianum Fenzl., Verbascum wiedemannianum Fisch. \& Mey., Sideritis libanotica Labill. subsp. linearis (Bentham) Borm., Centaurea mucronifera DC. and Hieracium cappadocicum Freyn from Turkish flora. Food Chem 2006; 98: 9-13.

42. Zengin G, Aktumsek A, Guler GO, Cakmak YS, Kan Y. Composition of essential oil and antioxidant capacity of Centaurea drabifolia Sm. subsp detonsa (Bornm.) Wagenitz, endemic to Turkey. Nat Prod Res 2012; 26: 1-10.

43. Marathe SA, Rajalakshmi V, Jamdar SN, Sharma A. Comparative study on antioxidant activity of different varieties of commonly consumed legumes in India. Food Chem Toxicol 2011; 49: 2005-12.

44. Wang $\mathrm{T}$, Jonsdottir R, Olafsdottir G. Total phenolic compounds, radical scavenging and metal chelation of extracts from Icelandic seaweeds. Food Chem 2009; 116: 240-8.

45. Aktumsek A, Zengin G, Guler GO, Cakmak YS, Duran A. Screening for in vitro antioxidant properties and fatty acid profiles of five Centaurea L. species from Turkey flora. Food Chem Toxicol 2011; 49: 2914-20.

46. Alzheimer Association. 2014 Alzheimer's disease facts and figures. Alzheimer's \& Dementia 2014; 10: e47-e92. [Avaliable at ; https://www.alz.org/downloads/facts_figures_2014.pdf; Last access; 03.05.2016]

47. Whiting DR, Guariguata L, Weil C, Shaw J. IDF Diabetes Atlas: Global estimates of the prevalence of diabetes for 2011 and 2030. Diabetes Res Clin Pr 2011; 94: 311-21.

48. Murray AP, Faraoni MB, Castro MJ, Alza NP, Cavallaro V. Natural AChE Inhibitors from Plants and their Contribution to Alzheimer's Disease Therapy. Curr Neuropharmacol 2013; 11: 388-413.

49. Etxeberria U, de la Garza AL, Campion J, Martinez JA, Milagro FI. Antidiabetic effects of natural plant extracts via inhibition of carbohydrate hydrolysis enzymes with emphasis on pancreatic alpha amylase. Expert Opin Ther Targets 2012; 16: 269-97.

50. Kim YJ, Uyama H. Tyrosinase inhibitors from natural and synthetic sources: structure, inhibition mechanism and perspective for the future. Cell Mol Life Sci 2005; 62: 1707-23.

51. Bhat M, Zinjarde SS, Bhargava SY, Kumar AR, Joshi BN. Antidiabetic Indian Plants: A Good Source of Potent Amylase Inhibitors. Evid-Based Complement Alternat Med 2011: 1-6.

52. Gulacti T, Kusman T. Lamiaceae Family Plants as a Potential Anticholinesterase Source in the Treatment of Alzheimer's 
Disease. Bezmialem Science. 2014; 1: 1-25.

53. Kamagaju L, Morandini R, Bizuru E, Nyetera P, Nduwayezu JB, Stevigny C, et al. Tyrosinase modulation by five Rwandese herbal medicines traditionally used for skin treatment. J Ethnopharmacol 2013; 146: 824-34.

54. Ertas A, Goren AC, Boga M, Demirci S, Kolak U. Chemical Composition of The Essential Oils of Three Centaurea Species
Growing Wild in Anatolia and Their Anticholinesterase Activities. J Essent Oil Bear Pl 2014; 17: 922-6.

55. Ozsoy N, Kultur S, Yilmaz-Ozden T, CelikBO, Can A, Melikoglu G. Antioxidant, Anti-Inflammatory, Acetylcholinesterase Inhibitory and Antimicrobial Activities of Turkish Endemic Centaurea Antiochia Var-Praealta. J Food Biochem 2015; 39: 771-6. 